\title{
Issues of technological regulation in urban development
}

\author{
Dmitry Spitsov*, and Igor Yazhlev \\ Moscow State University of Civil Engineering, Yaroslavskoe shosse, 26, Moscow, 129337, Russia
}

\begin{abstract}
The article is devoted to the problems of the development of environmental and industrial legislation in Russian Federation with regard to transition to the new principles of environmental management, to reduce negative impacts on the environment through the modernization of basic production assets, the use of innovative methods of management of production processes and business entities.
\end{abstract}

\section{Introduction}

Moscow is one of the most dynamically developing megacities in the world in terms of urban planning. In 2019, 10.4 million square meters real estate were built. A significant part of capital construction projects being commissioned require measures to ensure environmental safety and environmental protection at all stages of the life cycle of construction products during territorial planning, urban zoning, architectural and construction design, construction, capital repairs, reconstruction of capital construction projects, operation of buildings and structures. On April 20, 2020, the Moscow clinical center for infectious diseases in the Voronovskoye district, a green zone of the city, was put into operation. It is one of the largest construction projects implemented in recent years in Moscow, with a capacity of more than 800-900 hospital beds. Almost a thousand medical specialists will provide assistance here. The object was built within record time of 1 month. On a plot of more than 40 hectares, there are 50 single-story buildings and $142-3$-story buildings with a total area of 80,000 sq. m. [1]

There was paid special attention to ensuring environmental and sanitary-epidemiological safety. There has been met all regulatory requirements for the placement of a clinical center. In accordance with the provisions of SanPiN 2.1.3.2630-10 "Sanitary and epidemiological requirements for organizations engaged in medical activities", medical organizations that provide medical care in stationary conditions, providing round-the-clock medical monitoring and treatment of infectious diseases are located at a distance of at least 100 meters from the territory of residential development. Hospitals of the specified profile with 1000 or more beds are located in a suburban or green zone. The established sanitary protection zone (SPZ) with a size of $250 \mathrm{~m}$ is 2.5 times larger than the required standards.

They created effective treatment facilities to prevent any waste that is contaminated or dangerous from entering the external environment. The wastewater disinfection system will allow for multi-stage cleaning. At the first stage, wastewater will be decontaminated in

* Corresponding author: dvs43000@yandex.ru 
fiberglass tanks with a volume of 650 cubic meters using chemical reagents. At the next stage, there is planned an additional installation of a water disinfection system with ultraviolet radiation. The effluents at the outlet will meet the regulatory quality requirements for wastewater.

The hermetic ventilation system of premises is one of the main systems for ensuring biological safety. It prevents the release of contaminated air into the external environment and its spread between rooms. They plan to clean and decontaminate the air supplied and removed from infectious premises with devices that ensure the effectiveness of inactivation of microorganisms at the exit from the installation of at least 99 percent. For this purpose, there are provided channel installations for air inactivation [1].

The scale of the tasks to be solved in the operation of such a large capital construction project, and as shown above, the volume of use of natural resources and negative impact on the environment, will require new approaches to regulating issues of reducing negative impact, protecting the environment and ensuring environmental safety based on the principles of best available technologies (BAT) [10].

\section{Methods}

In accordance with the Federal Law "On Environmental Protection", technological standards are the standards for emissions, discharges of pollutants, standards for permissible physical impact. They are established using technological indicators.

Technological standards are developed and established at enterprises and organizations of the 1st category that have a significant negative impact on the environment based on the volume of emissions of pollutants, the volume of consumption of energy, raw materials and other resources per unit of production. However, the technological standards are also established for objects of centralized water disposal systems of settlements or urban districts classified as category II objects, if they are issued a comprehensive environmental permit for technologically regulated substances in accordance with the procedure established by the Federal law "On environmental protection" and the decree of the Government of the Russian Federation of October 26, 2019. No. 1379 "Rules for classifying water bodies for the purpose of establishing technological indicators of BAT in the field of wastewater treatment using centralized water disposal systems of settlements and urban districts". At the same time, the main marker pollutants are regulated for the applied technological process. Rules for the development of technological standards are established by the order of the Ministry of natural resources and ecology of Russia dated 14.02.2019 No. 89 "Rules for the development of technological standards"(Fig. 1) [2, 3].

Technological standards are set based on technological indicators. In turn, technological indicators are indicators of the concentration of pollutants, the volume and (or) mass of emissions, discharges of pollutants, waste production and consumption, water consumption and use of energy resources per unit of time or unit of production (goods), work performed, services rendered.

Technological indicators of the best available technologies should be established by regulatory documents in the field of environmental protection no later than six months after the publication or updating of information and technical reference books on the best available technologies. The technological indicators are specified in the main information and technical reference books (Table 1). For example, ITS 10-2015 "Wastewater treatment using centralized wastewater systems in settlements, urban districts", ITS 8-2015 "Wastewater treatment in the production of products (goods), work and services at large enterprises" and others. 
This approach can be compared with that outlined in Directive 2010/75 / EU of the European Parliament and the Council of November 24, 2010 on Industrial Emissions (Integrated Prevention and Control).

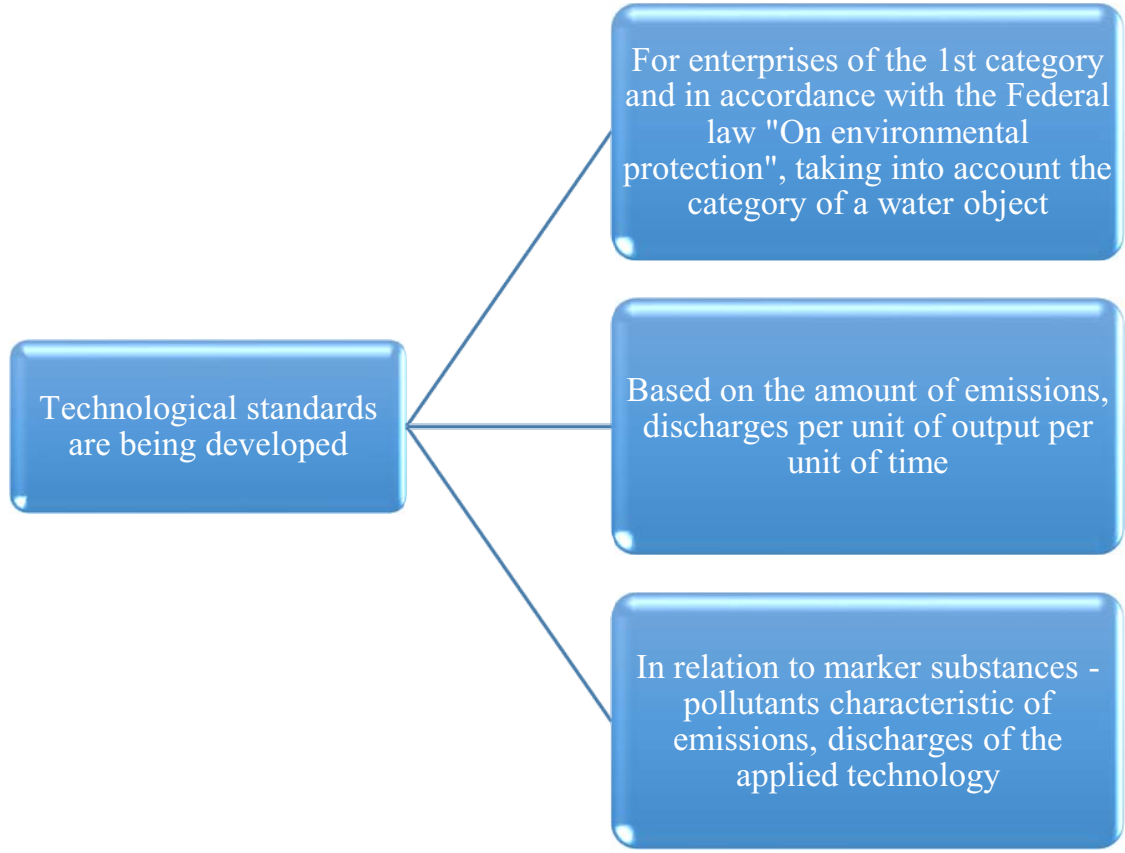

Fig. 1. Conditions for the development of technological standards

According to the Directive, BAT reference documents, drawn up for defined activities and describing applied techniques, present emissions and consumption levels, set the "emission levels associated with the best available techniques (BAT AELs)".

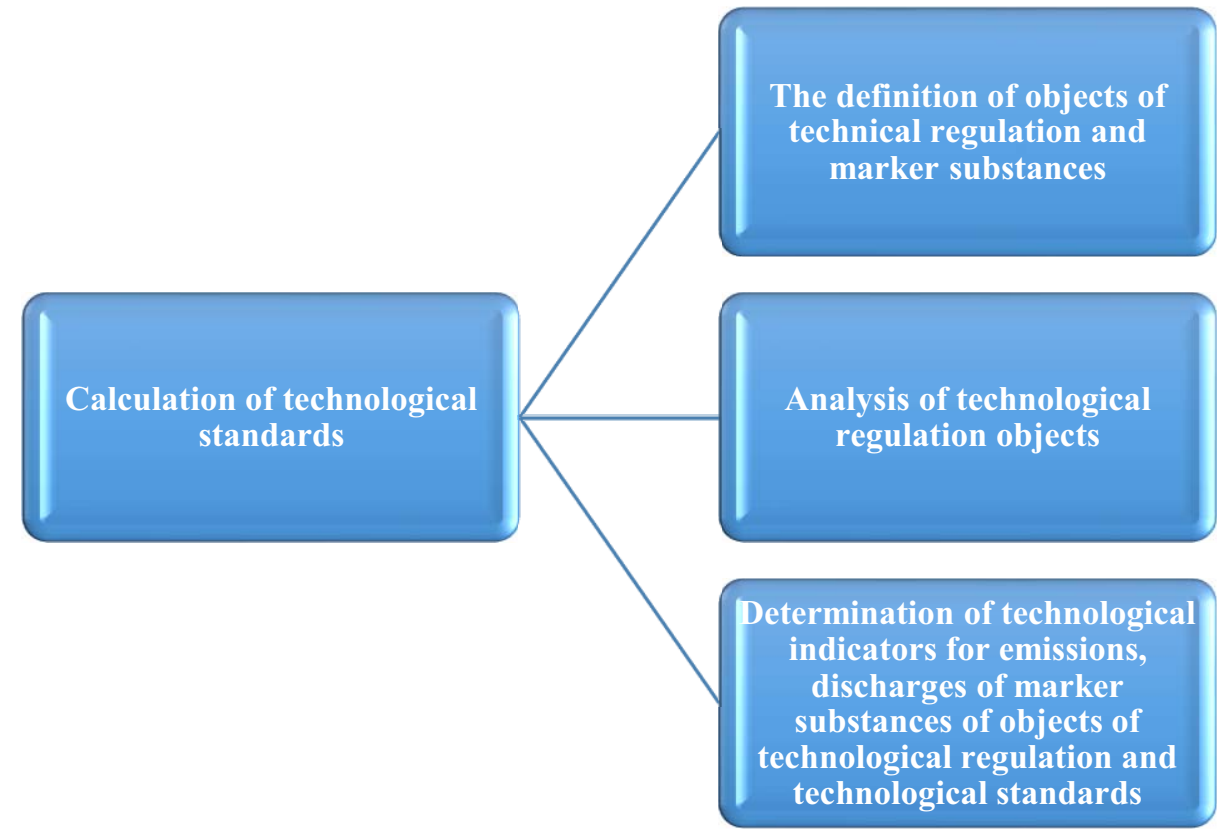

Fig. 2. The procedure for calculating technological standards. 
BAT AELs means the range of emission levels obtained under normal operating conditions using a best available technique or a combination of best available techniques, as described in BAT conclusions, expressed as an average over a given period of time, under specified reference conditions $[4,5,6]$.

For example, Best Available Techniques (BAT) Reference Document for Waste Treatment (2018) lays down information to asses BAT applicability for mechanical treatment of waste and the emissions levels associated with BAT (BAT AELs), including in order to reduce emissions to air of dust, and of particulate-bound metals, PCDD/F and dioxinlike PCBs (Table 1) [7].

Table 1: BAT-associated emission level (BAT-AEL) for channeled dust emissions to air from the mechanical treatment of waste.

\begin{tabular}{|c|c|c|}
\hline Parameter & Unit & $\begin{array}{c}\text { BAT-AEL } \\
\text { (Average over the sampling period) }\end{array}$ \\
\hline Dust & $\mathrm{mg} / \mathrm{Nm} 32-5(1)$ & $2-5(1)$ \\
\hline \multicolumn{2}{|c|}{ (1) When a fabric filter is not applicable, the upper end of the range is $10 \mathrm{mg} / \mathrm{Nm}$} \\
\hline
\end{tabular}

The technical standards stipulated by the Federal law "On environmental protection" are established for engines of mobile sources of environmental pollution in accordance with the levels of permissible impact on the environment. They are established by technical regulations adopted in accordance with the legislation of the Russian Federation on technical regulation.

In accordance with the rules for the development of technological standards, approved by order of the Ministry of Natural Resources and Ecology of Russia dated 14.02.2019 No. 89 "Rules for the development of technological standards", the procedure for developing technological standards in terms of emissions and discharges of pollutants is determined.

Table 2. Technological indicators BAT $11 \mathrm{~b}$ "Aerobic stabilization of dehydrated sediments (composting)" (ITS 10-2015)

\begin{tabular}{|l|c|c|}
\hline \multicolumn{1}{|c|}{ Technological indicator } & Unit & $\begin{array}{l}\text { Range of } \\
\text { values 3) }\end{array}$ \\
\hline $\begin{array}{l}\text { Efficiency of reducing organic matter sediment as a result of } \\
\text { treatment using the BAT 11b 1 technology 1) }\end{array}$ & $\%$ & More 22 \\
\hline $\begin{array}{l}\text { 1) excluding the use of additives (substances added to the sediment) during composting } \\
\text { 3) the indicated values are given as average annual }\end{array}$ \\
\hline
\end{tabular}

Technological regulations are developed for the object, that have negative impact on environment, and also for its parts (objects of technological regulation), where there are implemented or planned to implement technological processes, used equipment, used technical means and methods in the production of goods, performance of works, rendering of services in respect of which in the information technical reference books on best available techniques describes identical technological processes, equipment, technical methods, as well as technological indicators of the best available technologies, including for emissions, discharges (BAT technological indicators) (table 4) [2].

Table 3. The list of marker substances in accordance with ITS 10-2015 "Wastewater treatment using centralized sewage systems of settlements, urban districts"

\begin{tabular}{|l|c|}
\hline \multicolumn{1}{|c|}{ For atmospheric air } & For water bodies \\
\hline Hydrogen sulphide & Petroleum products - for surface wastewater discharges \\
\hline
\end{tabular}


The calculation of technological standards begins with the definition of objects of technological regulation and marker substances and is carried out by analyzing the available technical, design and operational documentation (Fig. 2) (table 5, 6) [2].

Table 4. General procedure for developing technological standards

\begin{tabular}{|c|c|c|c|c|c|}
\hline $\begin{array}{l}\text { Who develops } \\
\text { technological } \\
\text { standards }\end{array}$ & $\begin{array}{l}\text { Development } \\
\text { goal }\end{array}$ & $\begin{array}{l}\text { For which } \\
\text { objects of } \\
\text { technological } \\
\text { regulation }\end{array}$ & $\begin{array}{l}\text { For which } \\
\text { pollutants }\end{array}$ & $\begin{array}{l}\text { Calculation of } \\
\text { technological } \\
\text { standards }\end{array}$ & $\begin{array}{l}\text { The result of } \\
\text { the } \\
\text { development of } \\
\text { technological } \\
\text { standards }\end{array}$ \\
\hline $\begin{array}{l}\text { Legal entity, } \\
\text { individual } \\
\text { entrepreneur, } \\
\text { carrying out or } \\
\text { planning to } \\
\text { carry out } \\
\text { economic and } \\
\text { (or) other } \\
\text { activities at } \\
\text { facilities of } \\
\text { category I, as } \\
\text { well as at } \\
\text { facilities of } \\
\text { category II in } \\
\text { accordance } \\
\text { with the } \\
\text { Federal Law } \\
\text { "On } \\
\text { Environmental } \\
\text { Protection" }\end{array}$ & $\begin{array}{l}\text { Preparation of } \\
\text { an application } \\
\text { for a } \\
\text { comprehensive } \\
\text { environmental } \\
\text { permit (CEP) } \\
\text { or an } \\
\text { application for } \\
\text { a review of } \\
\text { CEP. }\end{array}$ & $\begin{array}{l}\text { Planned for } \\
\text { commissioning } \\
\text { and } \\
\text { operating objects } \\
\text { of negative } \\
\text { impact. }\end{array}$ & $\begin{array}{l}\text { For which } \\
\text { technological } \\
\text { parameters } \\
\text { of BAT are } \\
\text { established } \\
\text { for } \\
\text { emissions, } \\
\text { discharges } \\
\text { (marker } \\
\text { substances). }\end{array}$ & $\begin{array}{l}\text { determination } \\
\text { of objects of } \\
\text { technological } \\
\text { regulation } \\
\text { and marker } \\
\text { substances; } \\
\text { analysis of } \\
\text { technological } \\
\text { regulation } \\
\text { objects; } \\
\text { determination } \\
\text { of } \\
\text { technological } \\
\text { indicators for } \\
\text { emissions, } \\
\text { discharges of } \\
\text { marker } \\
\text { substances of } \\
\text { objects of } \\
\text { technological } \\
\text { regulation } \\
\text { and } \\
\text { technological } \\
\text { standards; }\end{array}$ & $\begin{array}{l}\text { Calculations } \\
\text { of } \\
\text { technological } \\
\text { standards } \\
\text { that are } \\
\text { included in } \\
\text { the } \\
\text { application } \\
\text { for obtaining } \\
\text { CEP or } \\
\text { application } \\
\text { for revision } \\
\text { of CEP. }\end{array}$ \\
\hline
\end{tabular}

The next step in the calculation of technological standards is the analysis of technological regulation objects for existing and planned objects that have negative impact on the environment. They carry it out using technical and project documentation (table 6.)

In accordance with the Rules of development of technological standards, approved by the Ministry of natural resources and ecology of Russia from 14.02.2019 No. 89, "Rules of development of technological regulations" determination of technological indicators for emissions, discharges of marker substances for each object of technological regulation is carried out in order to assess the compliance of technological indicators of emissions, discharges of the object of technological regulation with the technological indicators of BAT.

The indicators of marker substances emissions for each stationary source of emissions, indicators of marker substances discharges for each wastewater release as part of the object of technological regulation are determined for existing and planned enterprises using data obtained from the analysis and study of technical, operational and project documentation, information and technical reference books of BAT (Fig. 3).

The values of the annual gross emission, the annual discharge mass $(t /$ year) of each marker substance $M$ for the object of technological regulation are calculated as the sum of the mass of marker substance Mk emissions of all stationary sources of emissions (k), the sum of the mass of marker substance discharges Mk of all wastewater discharges (k) as part of the object of technological regulation. 


$$
\mathrm{M}=\sum_{k=1}^{\infty} \mathrm{Mk}
$$

Table 5. The procedure for determining the object of technological regulation.

\begin{tabular}{|c|c|c|}
\hline $\begin{array}{l}\text { Content of analysis of technical and operational } \\
\text { documentation }\end{array}$ & $\begin{array}{c}\text { For } \\
\text { operating } \\
\text { enterprises }\end{array}$ & $\begin{array}{l}\text { For planned } \\
\text { enterprises }\end{array}$ \\
\hline $\begin{array}{l}\text { - Technical documentation regulating carrying out of } \\
\text { technological operations; } \\
\text { - design and engineering documentation; } \\
\text { - technological regulations;; } \\
\text { - manual (instruction) for operation, technological } \\
\text { scheme; } \\
\text { - technical conditions; } \\
\text { - other operational documentation for the production of } \\
\text { products, performance of works, and provision of } \\
\text { services for existing facilities. }\end{array}$ & Yes & \\
\hline $\begin{array}{l}\text { Design documentation for the construction, } \\
\text { reconstruction of the capital construction facility for } \\
\text { the facilities planned for commissioning and } \\
\text { comparison with the relevant BAT information and } \\
\text { technical reference book (Table } 6 . \text {.) }\end{array}$ & & Yes \\
\hline \multicolumn{3}{|c|}{$\begin{array}{l}\text { The result of determining the objects of technological rationing and marker substances } \\
\text { are: } \\
\text { - list of identified objects of technological regulation; } \\
\text { lists of marker substances for which technological standards will be calculated for } \\
\text { each object of technological regulation and the object of negative impact (table 6). }\end{array}$} \\
\hline
\end{tabular}

Table 6. The content of the analysis of objects of technological regulation.

\begin{tabular}{|c|c|}
\hline \multicolumn{2}{|c|}{ Analysis of technological regulation objects } \\
\hline Operating objects & Designed objects \\
\hline $\begin{array}{l}\text { The analysis is performed using: } \\
\text { - technical documentation; } \\
\text { - inventory data on emissions of pollutants } \\
\text { into the air and their sources; } \\
\text { - inventory data on discharges of } \\
\text { pollutants into the environment and their } \\
\text { sources; } \\
\text { - results of industrial environmental } \\
\text { control for several years, but no more } \\
\text { than } 5 \text { years. }\end{array}$ & $\begin{array}{l}\text { They perform analysis using data from } \\
\text { project documentation for construction } \\
\text { and reconstruction of capital construction } \\
\text { projects. }\end{array}$ \\
\hline $\begin{array}{l}\text { As a result of the analysis of technological } \\
\text { for each technological rationing object: } \\
\text { - data on raw materials used and materials } \\
\text { - characteristics of manufactured products, } \\
\text { - characteristics of waste gases and gas-air } \\
\text { - list and parameters of stationary sources } \\
\text { of gas treatment plants and their efficienc }\end{array}$ & $\begin{array}{l}\text { tioning objects, the following are described } \\
\text { onsumed in the production process, } \\
\text { y-products and intermediates, } \\
\text { ows, } \\
\text { marker substances emissions, availability }\end{array}$ \\
\hline
\end{tabular}


- characteristics of wastewater,

- list and parameters of stationary wastewater sources (hereinafter - wastewater releases) containing discharges of marker substances,

- availability of facilities and devices for wastewater treatment and their characteristics.

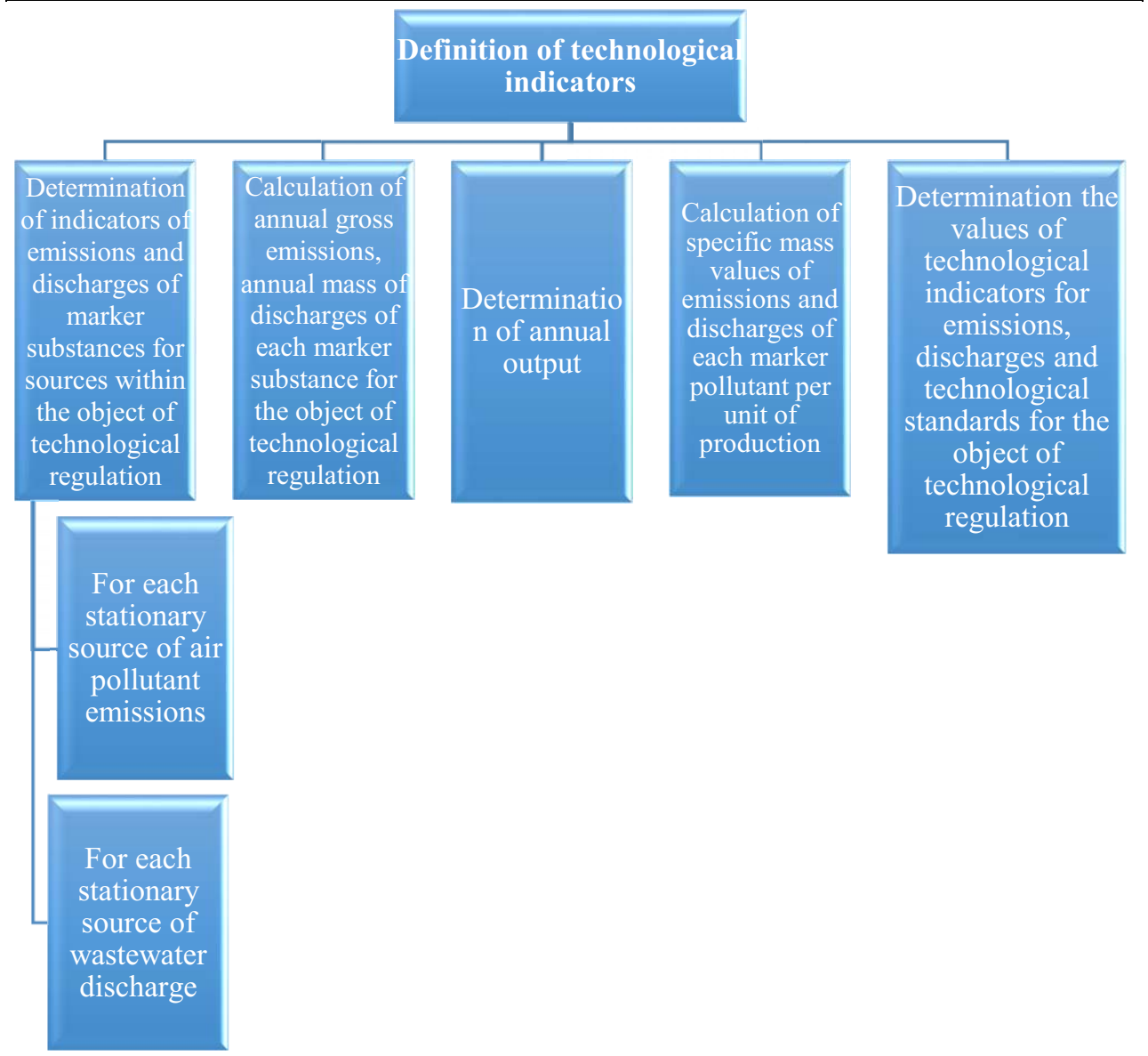

Fig. 3. The procedure of determination of technological indicators

The value of the annual output of $\mathrm{V}$ products is defined as an indicator of the maximum volume of products produced at the object of technological regulation during the year for several years, but no more than five years preceding the year in which calculations of technological standards are made.

The specific values for mass emissions, discharges each marker substances per unit of output Msp are calculated by dividing the annual gross emissions, the annual mass discharges of each marker substance on the amount of annual production at the object of technological regulation.

$$
M s p=\frac{\mathrm{M}}{\mathrm{V}}
$$

How to determine the values of technological indicators for emissions, discharges and technological standards for the operating object of technological regulation depends on if the technological indicators of BAT are set as a specific value of the mass of emissions, mass of discharges of marker substances per unit of production, or if the technological indicators of BAT for emissions, discharges are set as concentrations of marker substances (table 7.) [2]. 
Technological indicators for emissions and discharges of marker substances may not exceed the technological indicators of BAT for the objects designed and planned to be put into operation.

Table 7. Determination of values of technological indicators for emissions, water discharges and technological standards for the operating object of technological regulation.

\begin{tabular}{|c|c|}
\hline \multicolumn{2}{|c|}{$\begin{array}{l}\text { Procedure for determining the values of technological indicators for emissions, } \\
\text { discharges and technological standards for the operating object of technological } \\
\text { regulation: }\end{array}$} \\
\hline $\begin{array}{l}\text { Technological indicators of BAT are set in } \\
\text { the form of specific values of mass of } \\
\text { emissions, mass of discharges of marker } \\
\text { substances per unit of production: }\end{array}$ & $\begin{array}{l}\text { Technological indicators of BAT for } \\
\text { emissions and discharges are set in the } \\
\text { form of concentrations of marker } \\
\text { substances: }\end{array}$ \\
\hline $\begin{array}{l}\text { - the values of technological indicators } \\
\text { for emissions, discharges of marker } \\
\text { substances for the operating object of } \\
\text { technological regulation are assumed to } \\
\text { be equal to the specific values of the } \\
\text { mass of emissions, the mass of } \\
\text { discharges of this substance; }\end{array}$ & $\begin{array}{l}\text { - as a technological indicator for } \\
\text { emissions and discharges of a marker } \\
\text { substance of the object of technological } \\
\text { regulation, the highest value of the } \\
\text { concentration of this substance in the } \\
\text { emissions of stationary sources, } \\
\text { wastewater releases as part of the object } \\
\text { of technological regulation, determined } \\
\text { during the analysis of technical, } \\
\text { operational, project documentation and } \\
\text { BAT reference books is taken; }\end{array}$ \\
\hline $\begin{array}{l}\text { - if technological indicator for emissions, } \\
\text { discharges the marker substance is less } \\
\text { BAT technological indicator for } \\
\text { emissions, discharges the marker } \\
\text { substance or equal, in this case the } \\
\text { values of technological standards for } \\
\text { emissions, discharges on this marker } \\
\text { substance (t/year) is determined by } \\
\text { multiplying the technological indicator } \\
\text { for emissions, discharges the operating } \\
\text { object of technological regulation by the } \\
\text { amount of annual production; }\end{array}$ & $\begin{array}{l}\text { - if the technological indicator for } \\
\text { emissions and discharges of a marker } \\
\text { substance is less than or equal to the BAT } \\
\text { technological indicator of this marker } \\
\text { substance, then the value of the } \\
\text { technological standard for this marker } \\
\text { pollutant ( } \mathrm{t} / \mathrm{year} \text { ) is determined by } \\
\text { multiplying the specific value of the mass } \\
\text { of emissions, mass of discharges of this } \\
\text { marker substance by the value of annual } \\
\text { output; }\end{array}$ \\
\hline $\begin{array}{l}\text { - if the technological indicator for } \\
\text { emissions, discharges of marker } \\
\text { substance exceeds the technological } \\
\text { indicator of BAT for emissions, } \\
\text { discharges of this marker substance, then } \\
\text { the value of the technological standard } \\
\text { for emissions, discharges of this marker } \\
\text { substance ( } \mathrm{t} \text { / year) is determined by } \\
\text { multiplying the technological indicator } \\
\text { of BAT by the annual output of the } \\
\text { objects of technological regulation. }\end{array}$ & $\begin{array}{l}\text { - if the technological figure for } \\
\text { emissions, discharges at the marker } \\
\text { substance exceeds the BAT technological } \\
\text { indicator this marker substances, then the } \\
\text { value of the technological standard of this } \\
\text { marker pollutant (tons/year) determined by } \\
\text { multiplying the BAT technological } \\
\text { indicator by the annual value of the gas } \\
\text { emissions mixture or the annual } \\
\text { wastewater flow rate, determined } \\
\text { according to the program of ecological } \\
\text { efficiency }\end{array}$ \\
\hline
\end{tabular}

In accordance with the Rules of development of technological regulations, approved by order of the Ministry of natural resources and ecology of Russia from 14.02.2019 No. 89, 
technological standards for each marker substance for the object of technological regulation are defined as the sum of the technological standards of all objects of technological regulation in the object of technological regulation.

\section{Results and Discussions}

As noted above, the established system of technological regulation should help to reduce the negative impact on the environment, environmental risks, and the formation of an effective and environmentally oriented model for the development of urban development activities. However, this requires resolving a number of problems at this stage. For example, some already approved BAT information and technical reference books do not contain the values of technological indicators necessary for establishing technological standards and ensuring the operability of the new regulation system [8].

When updating BAT information and technical reference books the issues related to the environmental restoration of urban and industrial territories polluted by BAT application are also need to be reflected. This approach is presented in Directive 2010/75/EU of the European Parliament and of the Council of 24 November 2010 on industrial emissions (integrated pollution prevention and control). Where there is established that BAT reference documents should contain appropriate measures for remediation of contaminated sites [9].

\section{Conclusions}

Taking into account the established period of 7 years for updating the reference books, and the revision of technologies identified as the best available BAT technology is carried out at least once every ten years, the way out may be to improve existing and develop new national standards in this direction. For example, such as national standard GOST R 57446-2017 "Best available technologies. Reclamation of polluted land and sites. Restoration of biological diversity" and others [11].

This work was performed at the Department of Housing and Communal Services of the Institute of Engineering and Environmental Construction of the Moscow State University of Civil Engineering.

\section{References}

1. Hospital of infectious diseases in the area TiNAO Moscow. Complex of urban planning policy and construction of the city of Moscow. https://stroi.mos.ru/infiektsionnaia-bolnitsa-v-novoi-moskvie

2. Order of the Ministry of natural resources of the Russian Federation dated 14.02.2019 No. 89 "Rules for the development of technological standards". www.consultant.ru

3. Resolution of the Government of the Russian Federation of 26.10.2019 No. 1379 "On approval of the Rules for classifying water bodies as water bodies for the purpose of establishing technological indicators of the best available technologies in the field of wastewater treatment using centralized water disposal systems of settlements or urban districts". www.consultant.ru

4. Directive 2010/75/EU of the European Parliament and of the Council of 24 November 2010 "On industrial emissions (integrated pollution prevention and control)". https://eurlex.europa.eu/ browse/summaries.html

5. Best Available Techniques (BAT) Reference Document for Waste Incineration, Industrial Emissions Directive 2010/75/EU (Integrated Pollution Prevention and Control), Frederik 
Neuwahl, Gianluca Cusano, Jorge Gómez Benavides, Simon Holbrook, Serge Roudier. 2019. https://eippcb.jrc.ec.europa.eu/reference/

6. Best Available Techniques (BAT) Reference Document for Common Waste Water and Waste Gas Treatment/Management Systems in the Chemical Sector. Thomas Brinkmann, Germán Giner Santonja, Hande Yükseler, Serge Roudier, Luis Delgado Sancho, 2016. https://eippcb.jrc.ec.europa.eu/reference/

7. Best Available Techniques (BAT), Reference Document for Waste Treatment. Industrial Emissions Directive 2010/75/EU (Integrated Pollution Prevention and Control). Antoine Pinasseau, Benoit Zerger, Joze Roth, Michele Canova, Serge Roudier, 2018. https://eippcb.jrc.ec.europa.eu/reference/

8. Scientific and practical portal "Industrial Ecology". Environmental news. 22.4.19. Comment to the order of the Ministry of natural resources and ecology of the Russian Federation dated 14.02.2019 No. 89 "on approval of rules for the development of technological standards". www.ecoindustry.ru/news/view/55194

9. Boravsky B. V., Kostyleva N. V., Racheva N. L. Standardization and best available technologies in the mineral resource complex// Mineral resources of Russia. Economics and management, 2018, no. 5, pp. 66-70

10. "Integrated approach to green construction of buildings and structures". Soloduhin G. M., Yazhlev I. K. Privolzhsky scientific journal. 2014. no. 3 (31). Pp. 166-170.

11. Igor Yazhlev, Dmitry Spitsov and Alexander Popkov, E3S Web of Conferences 210, 13023 (2020) ITSE-2020, https://doi.org/10.1051/e3sconf/202021013023 